\title{
From Jacobs to the Just City: A Foundation for Challenging the Green Planning Orthodoxy
}

James J.T.Connolly

IMIM - Biomedical Research Park of Barcelona, Carrer Doctor Aiguader, 88, 08003, Barcelona, Spain.

Autonomous University of Barcelona (UAB), Institute of Environmental Science and Technology (ICTA), Building Z, Campus of the UAB, 08193 Bellaterra (Cerdanyola del Vallès), Barcelona, Spain

jamesjohntimothy.connolly@uab.cat

\section{Introduction}

Jane Jacobs became the most famous critic of 1960s urban planning orthodoxy by articulating a clear counter institutional position. She did so with directness. The introduction to The Death and Life of Great American Cities (1961) began, "This book is an attack on current city planning and rebuilding" (p.3). The remainder of the text contained vitriol for planning institutions and the laws, norms, and intellectual pursuits that supported them. She particularly targeted planning theory and the planning educators who ascribed to it, arguing that graduate schools of planning were guilty of perpetuating a fundamental misunderstanding of cities. Jacobs called the field a "pseudo-science" that was in a phase of development akin to the period for medical practice when bloodletting was commonly accepted.

Demonstrating the effectiveness of her blunt counter-institutional argument, during the late twentieth century Jacobs' collective thesis on cities became a central reference for a heterogeneous set of ideas that formed a new urban planning orthodoxy. By the 1990s, advocacy planners saw in her work a call for targeted representation of populations affected by urban development (Drier, 2006); participatory planners found a message of deep democracy (Alvarez, 2012); New Urbanist planners preached her gospel of physical diversity and human scale (Duany et al., 2001); urban environmental sustainability and smart growth advocates found in Jacobs a 
localized and people-oriented environmentalism (SSP, 2011); and design oriented planners saw her ideas as central to efforts to reshape contemporary urban form (Chantry, 2012). Even planners who specialized in urban economic development, for whom Jacobs reserved her most potent venom, came to see her later books (Jacobs, 1969; Jacobs, 1985) as visionary works that ascribed value to mixed use models of development (Taylor, 1998, p. 153).

Jacobs was also embraced by the new wave of social science-oriented planning educators that began to occupy graduate schools after the 1960s. As a result, her writings appeared in commonly assigned texts for introductory urban planning courses in the same graduate schools that she derided (Campbell and Fainstein, 1996; LeGates and Stout, 1996). As well, her books became standard reading for urban scholars, with The Death and Life of Great American Cities cited in academic publications more than 16,000 times by 2017. Indeed, her way of seeing the city was emblematic of the new academic vision for the planner's gaze - it was a perspective more interested in social systems than physical structures.

Based on the embrace from the planning profession and academy, it might be concluded that Jacobs' intellectual project was successful. While some areas of study, such as economic geography and urban sociology, continue to debate her arguments, the Jacobsian view on cities has generally guided planning orthodoxy since at least the 1990s. Representative of the nearly paradigmatic status of her ideas, those who are perceived as most supporting the Jacobsian approach are widely honored among urbanists: The Jane Jacobs Prize was inaugurated by Toronto's “spacing" group in 1997; The Urban Communication Foundation's Jane Jacobs book award was inaugurated in 2005; and The Rockefeller Foundation's Jane Jacobs Medal began in 2007. Yet, if Kuhn (1962) was correct when he argued that progress in scientific knowledge is dependent on the continued presence of voices challenging orthodox thinking, then planners 
need to ask: How will Jacobs' institutional goal of progressive change in the planning field be sustained in a time when reference to her ideas is no longer counter institutional? More broadly, how do we now build a new model for progressive urban planning?

In this article, I develop an original outline of the contemporary planning orthodoxy and empirically demonstrate cracks in one element often given (rightly or wrongly) a Jane Jacobs stamp of approval - urban greening initiatives. While Jacobs herself was skeptical of making cities greener just for the sake of greening, high profile greening initiatives have been honored with Jane Jacobs awards and are generally framed as part of her vision for diverse and active urban environments. These initiatives are said to address Jacobs' assertion that physical spaces should be designed to preserve social relations. They are emblematic of the reduction that has occurred over the years of Jacobs" critique into an argument for "livability" in cities, which generally focuses only on Jacobs' celebration of dense, lively, and diverse physical environments and sometimes justifies gentrification-oriented development to the detriment of the people who Jacobs championed - existing neighborhood residents.

I explore the implications for cities and specifically ask: what has been the relationship between greening and gentrification in New York since the 1990s? Unlike prior studies of green gentrification, I use a quantitative citywide analysis of gentrification and greening trends in order to exemplify this trend. I analyze the case of New York City between 1990 and 2014 and find potentially serious issues that result from an over-valuation of Jacobsian urban diversity. I then employ the Just City framework as a way of demonstrating the shortcomings of this perspective and some potential solutions for the planning field (Fainstein, 2010). In marrying an empirical analysis of urban greening's potential social effect with the Just City framework, this article demonstrates that, while Jacobs' original project and the current Just City project are distinct 
intellectual endeavors, they share a complementary goal of creating progressive change in the contemporary institutions that support the orthodoxy of urban planning. In this way, the two concepts are connected and form an important counter-institutional strand within urban scholarship.

\section{The Post War Orthodoxy of the "Radiant Garden City Beautiful"}

In The Death and Life of Great American Cities, Jane Jacobs described the goal of 1960s planning orthodoxy in the United States as the "Radiant Garden City Beautiful." The term is a mashup of three planning theories. First, in the 1920s the prominent modernist architect LeCorbusier presented his utopian vision of The Radiant City filled with high rise buildings surrounded by green space, a so-called towers in the park model. Jacobs saw this as an egodriven notion of planning that had little concern for how people actually lived but served well the purposes of large scale-urban renewal. In its anti-urban bias, she saw the Radiant City as a vertical interpretation of the second reference in her mashup, Ebenezer Howard's Garden City. Howard published his book on garden cities in 1898. It was a model of urban development that sought to integrate social and environmental goals within medium sized satellite towns. Actual garden cities began to be built in England in the early 1900s and the notion was adopted by the Regional Plan Association of America in the 1920s (Hall, 1988, Chapter 4). Jacobs saw garden cities and the regional planning approach in the United States as "decentrist" and essentially antiurban. Finally, the City Beautiful Movement that grew after the 1893 Chicago World's Columbian Exposition showcase of neoclassical architecture advocated monumental buildings and tree-lined boulevards as a means for creating civic pride in American cities. Jacobs objected to the sorting out of monumental and everyday urbanism. 
In identifying the Radiant Garden City Beautiful, Jacobs defined a basic problem with "the principles and aims that have shaped modern, orthodox city planning and rebuilding" (Jacobs, 1961, p.3). She found that the reigning orthodoxy ignored on-the-ground evidence of what made streets safe, what made for great public spaces, why disinvested areas regenerate, why downtowns grow, and what made neighborhoods attractive. Rather than celebrating the city for what it was, she argued, planners and developers made the city into what it was not - mainly a reflection of idealized suburban or utopian models for growth. She argued that the housing projects, downtown redevelopments, and new cultural centers being built in the Radiant Garden City Beautiful model during the postwar period of urban renewal in American cities were generic, dull, and blind to the value of existing neighborhoods. The solution to this problem was to move away from the abstract theories of urbanism and toward a grounded observation of what cities were like, especially for the people living in them.

In celebrating street-level urbanism, the Jacobsian view on what planners should do focused on preserving and enhancing diversity within big cities and this prescription extended to urban greening. Her vision of urban diversity sought to expel sentimentality for nature as a separate force and rather see cities as part of nature (Jacobs, 1961, Chapter 5). In this way, there was room for integrating nature into cities to the extent that it was not for the purpose of imposing visual order, but rather for expanding the co-presence of diverse spaces. This was a critical view of the urban greening agenda which despised parks and gardens that tried to bring suburban ideals into the city. Rather, for Jacobs, park spaces were to be valued, but only as embedded areas with diverse uses that attracted a wide base of people and contained a variety of design elements that would make them gathering places. 
In short, greening that served the goals of diverse, active, neighborhood-scale urbanism was in line with the Jacobsian model. This approach highlights the fact that there are various ways of greening, and the dividing line is drawn according to who the green spaces serve and to what end. While the contemporary urban greening agenda often views itself as an extension of Jacobsian ideals of diverse urban environments, it does not always appreciate the mode of greening that Jacobs highlighted within her own work. As a result, urban greening is often employed within the contemporary planning orthodoxy in a manner that favors large-scale, high profile, socially homogeneous spaces rather than small-scale, heterogeneous and neighborhoodoriented spaces.

\section{The Contemporary Orthodoxy of the Smart Sustainable Resilient City}

If American planning orthodoxy of the 1960s could be described as the Radiant Garden City Beautiful, then today's orthodoxy might be the Smart Sustainable Resilient City. In the mid1990s, several state and federal initiatives in the United States simultaneously put forth an agenda under the banner of "growing smart" that encouraged compact, transit-oriented growth with some underlying goals for environmental and community improvement (Knaap, 2006). This was primarily a development agenda meant to counter the negative effects of urban sprawl by increasing density and transit. In essence, smart growth advocates sought to carve out a middle ground between the pro-growth and no-growth positions wherein the primary question became focused on what type of growth was best. Since the 1990s, smart growth has remained an amorphous but continual goal for planners. However, recent studies have found that the effects in cities where smart growth was most vigorously implemented were highly inequitable (Addison et al., 2013; Tretter 2013) 
Smart growth was a uniquely American variant of the international urban sustainability movement that also took shape in the mid-1990s. Following an increased scientific and political awareness of the negative environmental impacts of exponential human growth in the 1970s and 1980s, the attention of the global community turned toward implementing a new sustainable growth model. The dimensions of this model were comprehensively laid out in the 1992 United Nations Conference on Environment and Development (UNCED), where the challenge was framed as one of balancing between social equity, environmental protection, and economic growth. In the decades following UNCED, the United States and many other countries saw city planning as the preferred mechanism for figuring out the specifics of implementing these strategies. As a result, for those already focused on city planning, sustainability became a valuable political frame. This convergence of agendas created what Wheeler $(2013$, p.13) called "an era in which increasingly the goals of [urban] planning relate to the goals of sustainability." It also created a situation where "sustainability fixes" were used to justify rapid growth (Long, 2016).

Most recently, a new line of thinking about what makes for resilient urban environments has augmented smart growth and sustainability efforts. As climate change creates more unpredictable and intense weather events, and global terrorism generates increased threats of violent attacks, municipal governments look to increase resilience within this new riskscape. A resilient city is one that can adjust to changing conditions without fundamental failures to its basic systems - in the face of new environmental norms a resilient city finds a new stable state in which it continues functioning. Central to this approach, new grey and green infrastructure has been introduced in cities throughout the world. While these interventions are most visibly focused on climate adaptation and mitigation, they extend more widely into questions of which 
social and physical infrastructures support cooperative action relative to natural resource management (Ostrom and Schlager, 1996).

On one hand, resilience fits awkwardly into local sustainability and smart growth agendas because one could argue that a focus on resilience accepts an unsustainable future, merely asking localities to prepare for its effects. On the other hand, resilience requires the same type of political accommodations as sustainability but at smaller temporal and spatial scales. If "the rate of resilience seems to have increased...even as the methods of destruction have multiplied" (Vale and Campanella, 2005, p. 5), then it is because resilience expands the viewpoint on urban policy that sustainability ushered in. Without some degree of resilience, places cannot be sustainable. Without sustainability, no amount of resilience can manage the predicted global impacts.

New York City is an archetypal example of the Smart Sustainable Resilient City. This orthodoxy has fully permeated planning efforts in New York since the 1990s. Redevelopment of formerly industrial sites is central to New York's smart growth agenda that was formally launched at the state level in the early 1990s. Reflective of a longstanding focus on sustainability, the city created the Mayor's Office of Long-Term Planning and Sustainability in 2006 in order to maintain and implement an integrated plan known as PlaNYC 2030. With the transition to a new mayoral regime in 2014, the office was renamed the Mayor's Office of Recovery and Resiliency and PlaNYC 2030 efforts shifted toward the city's resilience plan, titled A Greener Greater New York. For all of these efforts, greening was central. The plans sought for example to facilitate urban agriculture and community gardens, plant one million trees, upgrade and create new parks, clean formerly industrial sites, and create incentives for green infrastructure (including green roofs, enhanced tree pits, bioswales, and pervious paving). 
In New York City, the connection between the new vision for greening and the Jacobsian vision of planning was made clear when three high profile Jane Jacobs Medals were given by the Rockefeller Foundation to urban greening pioneers. Joshua David and Robert Hammond received the Jane Jacobs Medal in 2010 for their work in bringing about the creation of Highline Park in lower Manhattan. Highline Park is an elevated park built on a former industrial railway that primarily serves as an amenity for extremely expensive real estate and is today seen as one of the most emblematic symbols of a city built only for wealthy residents and tourists. Hammond has since lamented the inequity associated with the park (Bliss, 2017). In 2010, the Jacobs medal was also given to Elizabeth Barlow Rodgers, who founded the Central Park Conservancy, a public-private group representing elite city residents. The Conservancy has long been seen as emblematic of efforts to use high quality urban green space as a means for increasing nearby property values. Then, the performer Bette Midler was given the medal in 2013 for her work in founding a greening organization, New York Restoration Project (NYRP). NYRP maintains gardens and parks throughout the city, many in rapidly gentrifying neighborhoods. Each of the greening projects led by these people were said to uphold the ideals of urbanism for which Jane Jacobs fought. Whether Jacobs would have personally supported these awards or not, her ideas and the motivations for these actions are intertwined; in New York City, greening of this type is seen as a tool for developing the diverse urban environments that Jacobs valued.

\section{The Just City and Contemporary Challenges to Orthodox City Planning}

Few have questioned urban greening as an orthodox value for progressive planning, but an emerging literature is beginning to interrogate whether greening efforts - especially the kinds awarded the Jane Jacobs Medal in New York City - are in fact helping or hindering the cause of 
social equity. This literature examines the relationship between green infrastructure and gentrification, and how the Smart Sustainable Resilient City framework both supports and conceals this relationship. Analyses in this area focus on "urban gentrification processes that are facilitated in large part by the creation or restoration of an environmental amenity" (Gould and Lewis, 2012, p.121). Overall, this literature seeks to understand how lower income and nonwhite populations are systematically denied access to the benefits of urban greening such as improved health and higher quality of life as a result of exclusionary gentrification and direct displacement in the very neighborhoods where advocates fought to improve conditions (Steil and Connolly, 2009; Dooling, 2009; Pearsall, 2010; Checker, 2011; Anguelovski, 2016).

A number of authors have recently observed green gentrification in New York City. Pearsall (2010) found that brownfield redevelopment programs created new types of social vulnerabilities throughout the city as a result of the threat of gentrification. Checker (2011) argued that a process of "environmental gentrification" appropriated the discourse of environmental justice in order to advance the purpose of expanding high-end housing development in the Harlem neighborhood. Curran and Hamilton (2012) found evidence of a green gentrification threat in the Greenpoint neighborhood, but also of local pushback against this threat. Meanwhile, Gould and Lewis (2016) found evidence of green gentrification around Prospect Park, Brooklyn Bridge Park, and Gowanus Canal.

The green gentrification perspective is a counter discourse within a contemporary planning scholarship and practice that generally focuses solely on the benefits of greening. Green gentrification scholarship points out that green spaces may evolve toward socially exclusive amenities and that, as a result, municipal representatives and sustainability advocates who uncritically accept calls for more urban green space may create new socio-spatial inequities 
(Pearsall and Anguelovski, 2016). In taking this position, the environmental gentrification thesis questions the deep alignment between environmental and economic goals that contemporary orthodox urban planning generates. It expands the criteria against which green interventions should be measured and argues along with many local community-based organizations who seek greater power in the planning process that we should be wary of the Smart Sustainable Resilient City agenda (Anguelovski, 2016). This line of inquiry raises a fundamental challenge to the Smart Sustainable Resilient City's Jacobs-approved model of greening: If Highline Park, Central Park, and the NYRP gardens are only beautiful stages upon which wealthy New Yorkers may engage in the urban diversity dance that Jane Jacobs celebrated, then have we made a just city? Should the equity and democracy of these spaces also be important considerations?

Fainstein (2010) is unequivocal: to the first question the answer is no, to the second yes. In her theoretical framework for a just city, she provides a pathway for how to expand the criteria against which greening should be judged. She argues that the three goals of equity, democracy, and diversity have to be balanced. In this way, a just city is "one where public investment and regulation would produce equitable outcomes rather than support those already well off' (p.3). To achieve this type of public investment in cities, Fainstein argues that diversity and democracy must be maintained, but cannot supersede equity. Thus, the Just City model brings together critical urban theory with "an emphasis on justice as process, rooted in communicative rationality, and an emphasis on justice as outcome, rooted in an analysis of political economy" (Steil and Connolly, 2018).

In her description of diversity as a virtue of the Just City, Fainstein struggles with the somewhat incommensurable breadth of use to which urbanists put the term. Jacobs is a central reference for Fainstein, though, who agrees that diversity is an essential aspect of a just city. She 
writes that diversity "encompasses reference to the physical environment as well as social relations, and refers to policy ambitions that go beyond encouraging acceptance of others to include the social composition of places" (p.67). Thus, to a greater extent than Jacobs acknowledged, diversity encompasses issues of race and class and includes active recognition of other groups.

In her Just City model, Fainstein highlights the tension between diversity and equity (p.71). Pointing out that urban diversity became a mantra of pro-growth coalitions in the early 2000s, she highlights the role of "Creative Class" economic development agendas in exacerbating income inequalities and continuing racial and gender divisions. These agendas put a high value on diversity, but a thin version that does not include active recognition across social divides or an effort to provide proportionate resources to the most disadvantaged (Steil and Delgado, this issue). Further, even this thin version of diversity eventually is undermined and erased with a rapid influx of creative class residents (Anguelovski 2016). In short, the Jacobsian model of diversity has been deployed by current practitioners as a means of justifying urban policy that contrasts with goals of equity. It is important to highlight, though, that while Jacobs did not take on deeper issues of race and active recognition, we cannot say if she would have supported the recent economic development agenda for which her ideas have been used as a justification.

Fainstein also highlights the requirement that diversity be backed by a robust democratic process in order to link with equitable outcomes. She writes, "the desirability of pressing for it [diversity] depends very much on the process by which it is achieved and the class and racial/ethnic context in which it operates" (p.77). In her treatment of democracy, Fainstein is careful not to equate it with justice directly. Democracy, she points out, can produce unjust 
outcomes as easily as just outcomes. However, she also writes, "planners can affect the character of deliberation and move participants toward a greater commitment to just outcomes" (p.66). Thus, democracy in the Just City model is mostly about putting all views on the table as decisions are made about what types of diversity and what distribution of urban amenities is desirable. The urban diversity agenda of pro-growth coalitions contrasts with this view of democracy in its failure to actively recognize other views, especially around issues of equity. For this reason, Fainstein's claim rings true: the desirability of pressing for diversity depends on the process by which it is achieved and the context.

Jacobs saw an injustice and was quite clear what it was. She saw the vulnerable as those in the way of 1960s planning orthodoxy. In the overwhelming drive to create the Radiant Garden City Beautiful, local residents who Jacobs argued were the ones who actually made things work in cities were unjustly pushed aside. In response to this injustice, Jacobs developed a critical counter discourse that has informed planners ever since. Meanwhile, Fainstein's Just City sees the vulnerable in a broader sense, those who are least well off. It begins from a premise that planning orthodoxy often favors those who are the most well off. It does so, she argues, because it does not balance between diversity, equity, and democracy. Rather, one goal is often favored at the expense of others. The result is unjust. In the case of urban greening as an example of current planning orthodoxy, Fainstein offers a strategy: expand the criteria against which greening is measured. In doing so, she offers a pathway toward a just green city. In the next sections, I outline exactly why this new pathway toward a just green city is needed by quantitatively examining the empirical effects of greening in the Smart Sustainable Resilient era of New York City. I also briefly run the results through the expanded filters suggested by Fainstein's Just City model in order to begin to outline how to move toward a just green city. 


\section{Material and Methods}

Both Jacobs and Fainstein relied heavily on observations of New York City; this study does the same. It uses data on municipally sponsored green infrastructure projects built in New York City since 1990 and the spatial extent of gentrification processes over the same time in order to quantify co-location between these processes. The purpose of this analysis is to show whether a key tool within the current planning orthodoxy, which places high value on Jacobsian spaces of diversity, produces a city that balances social equity and environmental improvement (as popular descriptions of urban sustainability suggest).

In order to measure the spatial extent of gentrification in New York City between 1990 and 2014 , this study relies on two well-documented prior studies that use the same units of analysis and together demonstrate where gentrification occurred over the period of interest. In the first study, the Furman Center (2016) identifies gentrifying "sub-borough areas" (these are similar to Community Districts, or a somewhat large approximation of neighborhood) by analyzing data on rents and demographic change between 1990 and 2014. This study identifies areas that experienced rent increases above the median between 1990 and 2014 as gentrifying and shows that other socio-economic indicators associated with gentrification including race, ethnicity, and income also changed to a significant extent in these areas.

The problem with the Furman Center approach comes in when you consider that some of the most intense gentrification in New York City occurred in small sections of sub-borough areas, but not across the entire area. Reflecting the limitations of the data, the Furman Center study misses some neighborhoods commonly understood to have gentrified during the period 
studied. These neighborhoods are simply classified as "higher income" and likely did not show rent changes above the median because of the variety of population contained within the relatively large sub-borough areas. In order to account for this limitation, a second study is used to expand the boundaries of gentrification in New York City during this period. Freeman and Braconi (2004) primarily sought to measure displacement effects from gentrification in New York City during the 1990s. While the findings from this study on displacement have been the subject of considerable debate among gentrification scholars (Marcuse, 2005; Newman and Wyly, 2006), whether gentrification occurred to some degree within parts of the sub-boroughs areas that they identify has not generally been challenged.

The study used a combination of local knowledge and census analysis to identify seven sub-borough areas as having gentrified in the 1990s. These areas saw greater than average increases in the proportion of whites, rental rates, educational attainment, and median income. These were also areas that the authors judged based on experience to have gentrified. This method of identification adds three sub-borough areas to the Furman Center boundaries. Together, the Furman Center (2016) and Freeman and Braconi (2004) studies identify 18 out of 55 sub-borough areas as gentrifying between 1990 and 2014 (Figure 1). This boundary almost certainly overestimates the actual area of gentrification in some neighborhoods because of the large size of sub-borough areas, but it is also inclusive of all neighborhoods where gentrification likely occurred. Thus, it is arguably a reasonable balance between data limitations with regard to measuring displacement and observations of actual gentrification processes.

In order to measure greening in New York City between 1990 and 2014, this initial study assembles a unique database that aggregates all new green infrastructure by sub-borough area. The data was acquired from various sources. These sources included: (1) from the New York 
City Parks department, the location of all new parks property acquired since $1990^{1}$; and (2) the location of all sites that have been greened under the "Greenstreets" program launched in 1996, which converts land on the right of way of traffic corridors to greenspace; (3) from the New York City Department of Environmental Protection the location of all green infrastructure projects - these projects were implemented since 1990 and only "green" projects (including green roofs, bioswales, enhanced tree pits, pervious pavement, and constructed wetlands) were selected; (4) from the nonprofit organization LivingLots, the location of all community gardens and community green spaces ${ }^{2}$; (5) from the City of New York, the block planting locations of all MillionTreesNYC street tree additions that were planted since 2007; and, also from the City, (6) data showing the location of street trees in $2014 .^{3}$

The greening data was aggregated by sub-borough area by summing the number, length or area of green infrastructure, as appropriate for each variable. Each sum was then normalized by the area of the neighborhood it fell within. Once this was complete, a composite greening score was calculated as the sum of the Z-score for the normalized result of each of the 6 data points described above. The Z-score sum was then divided by 6 in order to get a final composite greening score for each sub-borough area. Once the composite greening score was calculated, I measured the point-biserial correlation between that score and the binary gentrification measure ( 1 for gentrifying, 0 for not) in order to quantify the co-location between gentrification and greening in New York City between 1990 and 2014. This method demonstrates correlation, but does not identify the causal pathway between greening and gentrification, which is not possible

\footnotetext{
${ }^{1}$ In order to identify these properties, a multi-step data processing technique was used combining data from the latest 2016 release, the 1999 release, and manual correction.

2 Data downloaded on 01/03/2017 from https://livinglotsnyc.org/\#11/40.7300/-73.9900. Note that the majority of these spaces came on line after 1990, but the date could not be confirmed for all.

${ }^{3}$ Due to data unreliability for earlier years, this is treated as a static measure of greening meant to capture baseline conditions.
} 
without a finer disaggregation of the gentrification data and more information on possible modifying and mediating variables. The existing qualitative studies are best suited for understanding these causal pathways. As a result, the purpose here is to show whether the outcomes of the Smart Sustainable Resilient City are spatially aligned with the goals of the Just City.

\section{Results}

The results support the premise of the green gentrification literature focused on New York City. Figure 1 displays the distribution of the two data points. Gentrifying areas are concentrated in Manhattan, and parts of the Bronx, Brooklyn and Queens that are close to Manhattan. While greening has not been entirely concentrated in gentrifying areas, these areas have received a substantial portion of greening efforts.

The results of the point-biserial correlation between gentrifying areas and the composite greening score reveal a moderate positive correlation $(.47$, significant at the .01 level $)$ between the two processes. While these results cannot speak to the extent of causal connection between greening and gentrification, they do demonstrate support for the assertion that prior findings in New York City are indicative of citywide trends. There is a statistically significant positive correlation between greening and gentrification during the period between 1990 and 2014 . 


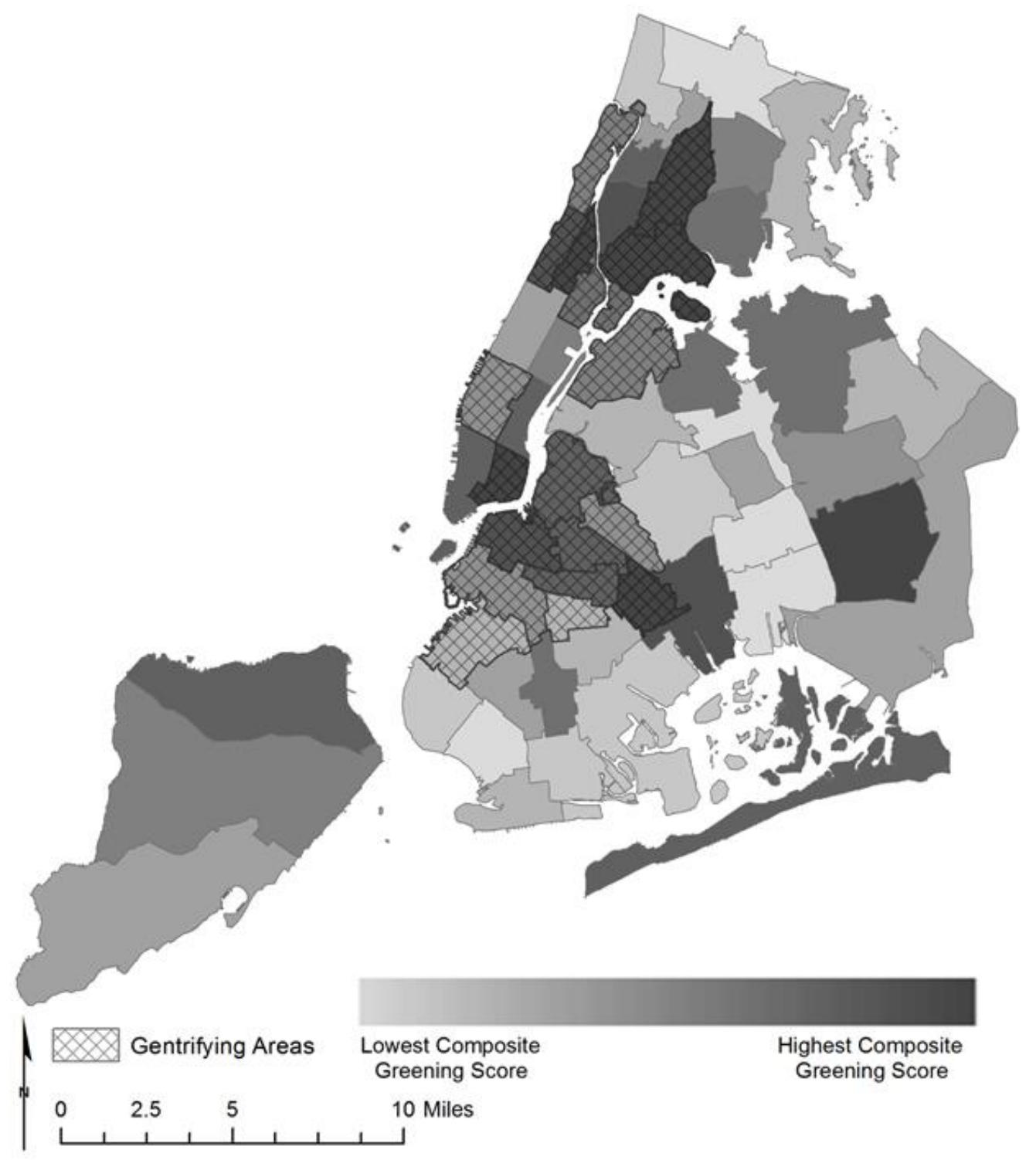

Figure 1. Greening Composite Scores and Gentrifying Areas. While greening is not solely concentrated in gentrifying areas, it does tend to be more concentrated in these areas than elsewhere and shows a statistically significant positive correlation.

\section{Discussion: Jacobs is not Enough for the Just Green City}

This paper uses the results of the above analysis of the social dynamics associated with greening in New York City to interrogate the Smart Sustainable Resilient City model. The results above provide a basis from which to ask how the broader criteria in the Just City model can be 
applied to greening in order to shift toward a just green city. This line of thinking then takes us back to the initial questions posed: How will Jacobs' institutional goal of progressive change in the planning field be sustained in a time when reference to her ideas is no longer counter institutional? More broadly, how do we now build a new model for progressive urban planning?

Green gentrification is a challenge to today's planning orthodoxy from a just city perspective. Fundamentally, a just greening policy for a city is one that produces equitable outcomes rather than targeted support for those already well off. It generates positive outcomes along the measures of diversity, democracy, and equity. If we examine urban greening in New York City, it does well from a diversity perspective. New green spaces in the form of gardens, parks, street enhancements, and rooftop greening have been introduced throughout the city. Many of these spaces adhere to Jacobs' prescription for parks as spaces that activate neighborhoods. The overall urban vitality and livability of New York City is generally improved by these spaces. Highline Park, one of the most visible examples of new urban greening initiatives, indeed deserves the Jane Jacobs medal in this regard as it furthers her vision of urbanism that embraces city life.

For the sake of space and because the focus here is on the equity implications of an overvaluation of Jacobsian diversity, a full study of the democracy criterion behind urban greening in New York is not possible. However, procedural justice questions related to urban environmentys are at the center of a long history of examinations taken up by environmental justice activists. Preliminary evidence in this case supports a mixed finding for democracy. A number of green spaces, such as community gardens, were developed in a grassroots fashion with considerable input and resources from multiple levels of government. At the same time, PlaNYC 2030 efforts were highly criticized for lack of consultation with stakeholders around green space provision 
outside of the core groups that wrote the plan. Further investigation would likely yield a high focus on democracy in some spaces and an elite-centered decision process in others (low democracy).

When green gentrification is considered, equity does the poorest of the three Just City criteria. As the analysis presented here and prior studies suggest, greening is positively associated with areas of long term exclusion of the least well off. Based on prior qualitative research, this association is strong around certain high-profile projects, but the analysis presented here shows that it holds to a moderate extent citywide. As a result, the benefits provided by greening and, ultimately, the benefits of urban life that Jacobs celebrated are not equitably distributed. Often greening is uncritically accepted because it is assumed to have only positive effects on city life. It is discussed in terms of universal benefits derived from improved ecological functioning, or from improved health access. In fact, though, greening benefits have, in spatial statistical terms, strong nonstationarity - the effect of greening is unevenly distributed across space. To simply universalize the benefits of greening is to ignore the extent to which these benefits are differently accessed by various income and race/ethnicity groups. It also ignores the dis-benefits that may result.

One way of describing the effect of green gentrification, at least in New York City, is that it creates a backwards proportionate universalism problem. If a proportionate univeralist approach to policy creates benefits accessed by all but targets those benefits more to the least well off, a substantial portion of greening in New York City seems to do the opposite. Indeed, there are benefits from the addition of green infrastructure to the city, but green gentrification targets those benefits toward the most well off. This argument does not mean that green gentrification was necessarily the intention of the New York City agencies in charge of green 
infrastructure, but it was the effect of some of their actions. To the extent that green

infrastructure serves as a tool for real estate investors to increase prices in formerly affordable areas without any housing controls in place for the existing community, this effect persists.

\section{Conclusion}

Jane Jacobs taught planners that homogenization kills the forces that make cities great, but her more important lesson was in teaching the field how to question its own orthodoxy. There is much work to be done in order to create a clear counter institutional position relative to the Smart Sustainable Resilient City and to create the conditions for that position to be adopted. Recently, a coalition of environmental justice groups in New York City convinced the government to shift its resilience agenda toward a primary focus on equity (New York City Environmental Justice Alliance, 2016). Efforts such as these, which expand the criteria against which greening is measured, are essential for creating conditions where counter-institutional just green city agendas can take hold.

This analysis, along with prior work on green gentrification in New York City demonstrates that the overvaluation of Jacobsian diversity tends to emphasize economic development goals within the Smart Sustainable Resilient City model over others. The result is to reward projects for creating diverse urban spaces, but also to pay far less attention to democracy and equity criteria. Green gentrification does not mean that cities should stop building green infrastructure. Rather, it means that they should do so with a just green city model in mind. 


\section{References}

Addison, C., Zhang, S., Bradley C. (2013) Smart Growth and Housing Affordability: A Review of Regulatory Mechanisms and Planning Practices. Journal of Planning Literature 28 (3):215257. doi: $10.1177 / 0885412212471563$.

Alvarez, A. (2012) New York City's Highline: Participatory Planning or Gentrification? The Penn State McNair Journal. 19; 1-14.

Anguelovski, I. (2016). Healthy Food Stores, Greenlining and Food Gentrification: Contesting New Forms of Privilege, Displacement and Locally Unwanted Land Uses in Racially Mixed Neighborhoods. International Journal of Urban and Regional Research.

Bliss, L. (2017) The Highline's Next Balancing Act. The Atlantic Citylab, February 7, Retrieved from http://www.citylab.com/cityfixer/2017/02/the-high-lines-next-balancing-act-fair-and-affordabledevelopment/515391/?utm_source=eb

Chantry, E. (2012, November 18) Urban Designer Series: Jane Jacobs, The Mother of Urban Design [Blog]. Retrieved from https://helmofthepublicrealm.com/2012/11/18/urban-designerseries-jane-jacobs/

Checker, M. (2011). Wiped out by the "greenwave": Environmental gentrification and the paradoxical politics of urban sustainability. City \& Society, 23(2), 210-229.

Curran, W., \& Hamilton, T. (2012). Just green enough: Contesting environmental gentrification in Greenpoint, Brooklyn. Local Environment, 17(9), 1027-1042.

Dooling, Sarah. (2009). Ecological Gentrification: A Research Agenda Exploring Justice in the City. International Journal of Urban and Regional Research, 33(3), 621-639.

Drier, P. (2006) “Jane Jcobs' Radical Legacy," Shelterforce Online, Issue \#146, Summer 2006, retrieved from http://nhi.org/online/issues/146/janejacobslegacy.html

Duany, A., Plater-Zyberk, E., \& Speck, J. (2001). Suburban nation: The rise of sprawl and the decline of the American dream. Macmillan.

Fainstein, S. S., \& Campbell, S. (Eds.). (1996). Readings in Planning Theory. Oxford: Blackwell.

Fainstein, S. (2010) The Just City. Cornell University Press.

Freeman, L., \& Braconi, F. (2004). Gentrification and displacement New York City in the 1990s. Journal of the American Planning Association, 70(1), 39-52. 
Furman Center (2016) Focus on Gentrification. A Special report of the Furman Center, New York City. Retrieved from http://furmancenter.org/files/sotc/Part_1_Gentrification_SOCin2015_9JUNE2016.pdf

Gould, K.A., \& Lewis, T.L. (2012). The world in brooklyn: Gentrification, immigration, and ethnic politics in a global city. In J. DeSena \& T. Shortell (Eds.), The environmental injustice of green gentrification: The case of Brooklyn's Prospect Park (113-146).

Gould, K. A., \& Lewis, T. L. (2016). Green Gentrification: Urban Sustainability and the Struggle for Environmental Justice. Routledge.

Hall, P. (1988) Cities of Tomorrow. Blackwell Publishing: Malden, MA.

Knaap, G. J. (2006). A Requiem for Smart Growth? Presented at "Planning Reform in the New Century," Washington University Law School, St. Louis, Mo, December, 2004. Accessed online January 3, 2017: http://smartgrowth.umd.edu/assets/knaap_2006.pdf

Jacobs, J. (1961, 1993 Modern Library Edition). The Death and Life of Great American Cities. Vintage.

Jacobs, J. (1969). The Economy of Cities. Vintage.

Jacobs, J. (1985). Cities and the Wealth of Nations. Vintage.

Kuhn, T.S. (1962). The Structure of Scientific Revolutions (1st ed.). University of Chicago Press. p. 172. LCCN 62019621.

LeGates, R. T., \& Stout, F. (Eds.). (1996). The City Reader. Routledge.

Long, J. (2016) Constructing the narrative of the sustainability fix: Sustainability, social justice and representation in Austin, TX." Urban Studies 53 (1):149-172. doi:

$10.1177 / 0042098014560501$.

Newman, K., \& Wyly, E. K. (2006). The right to stay put, revisited: gentrification and resistance to displacement in New York City. Urban Studies, 43(1), 23-57.

New York City Environmental Justice Alliance (2016) NYC Climate Justice Agenda:

Strengthening the Mayor's OneNYC Plan. Retrieved from http://nyc-eja.org/public/publications/NYC_ClimateJusticeAgenda.pdf

Ostrom, E., Schlager, E. (1996). The formation of property rights. In: Hanna, S., Folke, C. and Mäler, K.-G. (Eds.) Rights to nature: ecological, economic, cultural, and political principles of institutions for the environment, Island Press: Washington, 127-15. 
Pearsall, Hamil. (2010). From brown to green? Assessing social vulnerability to environmental gentrification in New York City. Environment and planning. C, Government \& policy, 28(5), 872.

Pearsall, H., \& Anguelovski, I. (2016). Contesting and Resisting Environmental Gentrification: Responses to New Paradoxes and Challenges for Urban Environmental Justice. Sociological Research Online, 21(3), 6.

SSP (2011, January 18) Jane Jacobs, The City, and Sustainability [Blog Post]. Retrieved from http://ssppjournal.blogspot.com.es/2011/01/jane-jacobs-city-and-sustainability.html

Steil, J., \& Connolly, J. (2009). Can the Just City be built from below? Brownfields, planning, and power in the South Bronx. Searching for the just city: debates in urban theory and practice. London, New York: Routledge, 173-193.

Steil, J. and Connolly, J. (2018) "The Just City" in Anthony M. Orum (ed.) The Wiley-Blackwell Encyclopedia of Urban and Regional Studies. Malden: Wiley-Blackwell.

Taylor, N. (1998) Urban Planning Theory Since 1945. Sage Publications; London and Thousand Oaks, Ca.

Tretter, E.M. (2013) Contesting Sustainability: 'SMART Growth' and the Redevelopment of Austin's Eastside. International Journal of Urban and Regional Research 37 (1):297-310.

UNEP (1972) Report on the United Nations Conference on the Human Environment. Retrieved from http://www.unep.org/Documents.multilingual/Default.asp?DocumentID=97

Wheeler, S. M. (2013). Planning for sustainability: creating livable, equitable and ecological communities. Routledge.

Vale, L. J., \& Campanella, T. J. (2005). The resilient city: How modern cities recover from disaster. Oxford University Press. 